\title{
Formation mechanisms of illite, chlorite and mixed-layer illite-chlorite in Triassic volcanogenic sediments from the Southland Syncline, New Zealand*
}

\author{
Jung Ho Ahn ${ }^{1, a}$, Donald R. Peacor ${ }^{1}$, and Douglas S. Coombs ${ }^{2}$ \\ ${ }^{1}$ Department of Geological Sciences University of Michigan, Ann Arbor, Michigan 48109, USA \\ 2 Department of Geology University of Otago, Dunedin, New Zealand
}

\begin{abstract}
Clay minerals from the three principal kinds of zeolitic sediments from the type area for zeolite facies alteration, the Triassic Murihiku Supergroup, Southland, New Zealand, have been studied by TEM. Bentonitic tuff consists largely of smectite and heulandite with minor illite; they occur as replacements of glass shards and are inferred to be direct alteration products of tuff alteration. Both analcime- and laumontite-rich tuffs contain chlorite, illite and mixed-layer illite-chlorite, including 1:1 mixed-layer sequences. Subhedral to euhedral phyllosilicate crystal shapes and other textural features imply that phyllosilicates crystallized from solution derived in part by dissolution of precursor smectite. Intralayer transitions involving illite and chlorite are inferred to be products of crystallization rather than direct alteration and replacement. Petrographically similar bentonitic and analcimized tuffs overlap each other in the stratigraphic section, supporting earlier observations that there is no systematic change in smectite relative to the illite plus chlorite derived from smectite in sections up to $8.5 \mathrm{~km}$ thick. The data imply that smectite may be metastable relative to illite plus chlorite. Permeability and fluid chemistry are inferred to be as significant as temperature in promoting reactions in clay minerals as well as zeolites during burial metamorphism.
\end{abstract}

\section{Introduction}

Coombs (1954) observed mineralogical changes broadly related to burial depth in Triassic volcanogenic sediments of the Murihiku Supergroup from the Taringatura Hills, Southland, New Zealand. Gross overlapping of key minerals in this sequence occurs commonly (Coombs 1954; Coombs et al. 1959; Boles and Coombs 1977). The rocks concerned were used as type examples of the zeolite facies (Coombs et al. 1959) and of burial metamorphism (Coombs 1961). Zen $(1961,1974)$ noted that a Ca-zeolite trend at low values of $\mathrm{CCO}_{2}$ can be distinguished from a clay mineral-carbonate trend for higher values of $\mu \mathrm{CO}_{2}$ during low-

* Contribution No. 436, from The Mineralogical Laboratory, Department of Geological Sciences, The University of Michigan, Ann Arbor, Michigan 48109

a Present address: Department of Geology, Arizona State University, Tempe, Arizona 85287

offprint requests to: D.R. Peacor temperature alteration. In volcanic and volcanogenic rocks the occurrence of various zeolites and other $\mathrm{Ca}-\mathrm{Al}$-silicates is diagnostic of increasing grade of metamorphism; in argillaceous rocks mineralogical changes in the clay minerals are of prime significance. In pelitic sediments, illite and chlorite increase in abundance at the expense of smectite with advancing diagenesis or metamorphism. Hower et al. (1976) described such mineralogical changes with the generalized reaction, $\mathrm{K}$-feldspar + smectite $=$ illite + chlorite + quartz.

Clay minerals in volcanogenic sediments are not as well studied as those of pelitic sediments although illite is generally thought to be less abundant and chloritic material is ubiquitous. The chlorite is commonly interlayered with other phyllosilicates. For example, Boles and Coombs (1977) reported variable but significant $\mathrm{Ca}, \mathrm{K}$, and $\mathrm{Na}$, low total cations, and $\mathrm{Al}^{\mathrm{VI}}>\mathrm{Al}^{\mathrm{VV}}$ in electron microprobe analyses of Fe-rich "chlorite" from zeolite facies sediments of the Murihiku Supergroup from the Hokonui Hills and Taringatura Hills, New Zealand. They suggested that about 5 to 20 percent of dioctahedral clays might be interlayered with the chlorite below the resolution of the electron microprobe. They also reported the presence in many rocks of celadonite and mixed-layer celadonite and chlorite (Boles and Coombs 1975). No high resolution data have hitherto been reported for such phyllosilicates from zeolite-bearing sediments, although there are relatively detailed TEM data on phyllosilicates in pelitic rocks (Lee et al. 1984; Ahn and Peacor 1985, 1986, 1987) and sandstones (Curtis et al. 1985).

We have carried out a TEM study of phyllosilicates in three Traissic zeolitic volcanogenic sediments from the coastal section north of Nugget Point, New Zealand. These rocks are petrographically equivalent to rocks previously described from the Taringatura Hills and Hokonui Hills further to the northwest in the Southland Syncline (e.g. Boles and Coombs 1975; Coombs et al. 1976).

\section{Geological setting}

Near Kaka Point on the southeast coast of Otago, South Island, New Zealand (Fig. 1) is a northward-younging Middle Triassic marine sequence of siltstones and subordinate volcanogenic sandstones, in all over $1.5 \mathrm{~km}$ thick. The section contains over 300 thin interbedded ash beds (Coombs et al. 1959; Coombs et al. 1976). These range from a few millimeters to a few decimeters in thickness; sedimentary 

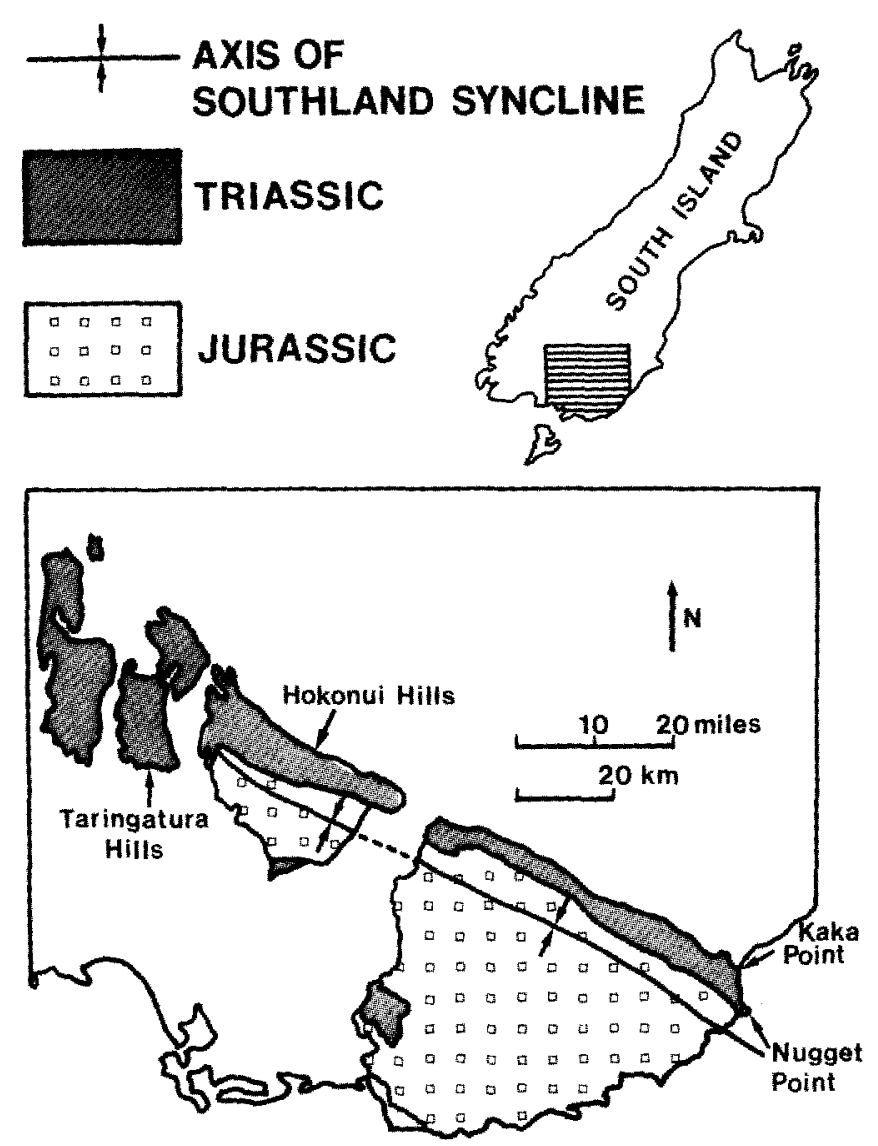

Fig. 1. Location map of Southland Syncline area, New Zealand, after McKellar (1976) and Boles and Coombs (1977)

structures commonly indicate that they are redeposited. Three main types may be distinguished. One type is bentonitic, commonly containing crystal clasts near the base and relict heulanditized glass shards. (The name heulandite is applied here to any member of the heulandite-clinoptilolite series; many Murihiku examples have an intermediate compositional range; Boles 1972; Boles and Coombs 1975.) Boles and Coombs (1975) reported that in 17 such bentonites examined from the Triassic section in the Hokonui Hills, smectites are predominant in most samples relative to subordinate illite. No consistent changes in clay minerals were detected with depth of burial.

A second type of tuff alteration is represented on the promontory of Kaka Point by thicker crystal vitric tuffs. They contain heulanditized glass shards, clasts of volcanic feldspar (mostly andesine), plentiful smectite outlining the heulanditized shards and filling microvesicles, and occasional chlorite.

The third type consists of cherty- or porcellanous-looking rocks in which original glass shards are replaced by analcime associated with fine-grained quartz and phyllosilicates. Smectite- and heulandite-rich ash beds may pass laterally into analcimized tuffs. Evidence has been given by Boles (1971) and Boles and Coombs (1975) that the analcime-quartz assemblage replaces a heulandite precursor by the action of low-temperature fluids of high $[\mathrm{Na}+] /[\mathrm{H}+]$ ratio.

The Kaka Point section has clearly not reached the limiting temperature of analcime plus quartz breakdown to albite. It thus corresponds to the lowest grade, uppermost half of the Taringatura and Hokonui Hills sections. It is unlikely that temperatures exceeded $50^{\circ} \mathrm{C}-100^{\circ} \mathrm{C}$ in the Kaka Point block.

An additional type of alteration described for ash beds in the Taringatura and Hokonui Hills (Boles and Coombs 1975) involves replacement of heulandite by laumontite plus very fine-grained quartz and alkali feldspars, with simultaneous albitization and often laumontitization of volcanic plagioclase clasts. Like replacement of analcime by albite, replacement of heulandite by laumontite involves a dehydration reaction and may be regarded as very low-grade metamorphic rather than diagenetic, sensu stricto (Coombs 1961). The temperatures at which these reactions take place under equilibrium conditions do not exceed about $180^{\circ}$ for pressures of 1-2 kbars (Liou 1971; Cho et al. 1986); however, they must depend on the precise composition of the analcime or heulandite, and may be reduced drastically where $P_{\mathrm{H}_{2} \mathrm{O}}$ is less than $P_{\text {lithostatic }}$. Decomposition temperatures were greatly reduced in permeable beds and along open joints, as compared with those in impermeable beds (Boles and Coombs 1977).

The laumontitic type of alteration is not observed in the Kaka Point block, but does occur in the thick southward-facing north limb of the Southland Syncline, exposed from Campbell Point southwards (Fig. 1). A specimen from the shore at a locality known as Park's Cutting, just north of Nugget Point, has been selected for study.

\section{Description of specimens}

Petrographic description and locality data for the specimens used for TEM study are as follows:

D 21 (OU 52329) Bentonite from Tilson Siltstone, near top of Etalian Stage, Middle Triassic, approximately $700 \mathrm{~m}$ north of Kaka Point promontory. The bed is about $10-20 \mathrm{~cm}$ thick, with thin silty laminae containing clasts of fresh, unaltered plagioclase and quartz about $60-\mu \mathrm{m}$ diameter together with numerous relicts of cuspate glass shards, some reaching $0.2 \mathrm{~mm}$. A concentrate of these yields an XRD pattern for heulandite. They are outlined by highly birefringent smectite. Microprobe analyses show that the feldspars are mostly $\mathrm{An}_{58-28}$, with a few grains of alkali feldspar. The matrix contains a very fine-grained aggregate of clay minerals together with tiny cubes and framboids of pyrite 1 to $20 \mu \mathrm{m}$ in diameter. XRD shows the presence of quartz, plagioclase, heulandite, abundant smectite with $20 \%$ randomly interstratified illite/smectite and a subordinate phyllosilicate having a principal peak at $7 \AA$.

D 13.2 (OU 52330) Analcimized ash bed from Bates Siltstone, Etalian Stage Middle Triassic, on south side of Kaka Point promontory as reported by Coombs (1965). A finely bedded crystal vitric tuff with well preserved vitroclastic texture and grain size approximately $0.1 \mathrm{~mm}$. In addition to the presence of analcime, quartz and plagioclase, XRD shows a broad $14-\AA$ peak which is unmodified by solvation with ethylene glycol, a strong $7-\AA$ peak and a weak $10-\AA$ peak. Electron microprobe analyses show that the detrital feldspars are mostly oligoclase, $\mathrm{An}_{18-30}$ accompanied by albite. Dark chlorite material occupying microvesicles has about $30 \% \mathrm{FeO}, 6 \% \mathrm{MgO}$ and significant $\mathrm{Na}$ and $\mathrm{K}$ suggesting the presence of interlayered dioctahedral phyllosilicate layers.

D 22A (OU 52331) Laumontitized vitric tuff from a bed approximately $1 \mathrm{~m}$ thick exposed in a small stack on the shore below Parks Cutting near Nugget Point. Laumontite has crystallized in domains which replace cuspate glass shards up to about $0.1 \mathrm{~mm}$ in size. The original shard outlines are preserved by films of brownish green optically negative "chlorite", which also occupy microvesicles in shards. Some plagioclase clasts, up to $0.4-\mathrm{mm}$ diameter, 


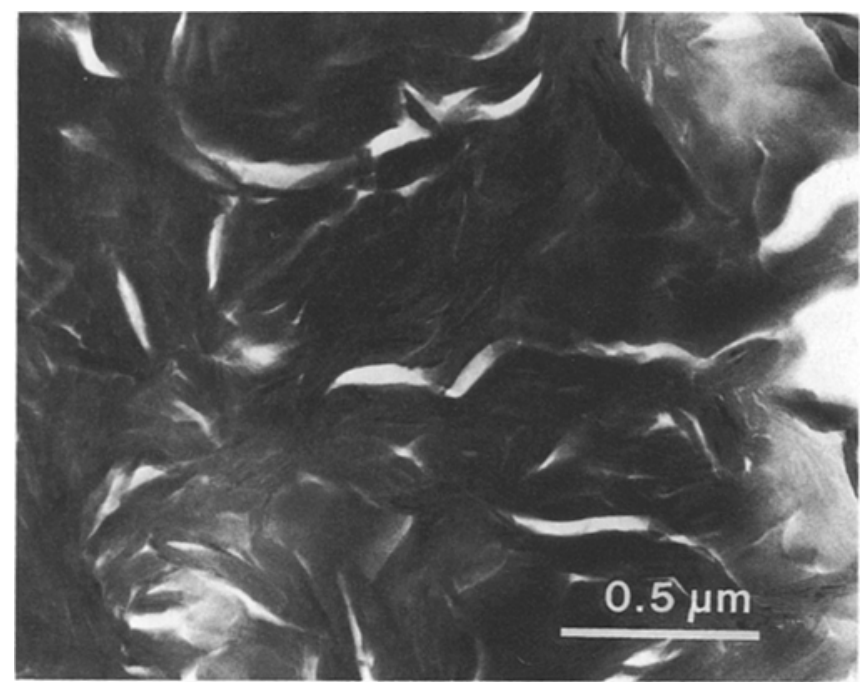

Fig. 2. Low magnification TEM images of smectite-rich bentonitic sediment (D 21.6, Kaka Point, New Zealand)

are entirely albitized and show a characteristic dusty clouding of microvacuoles (?). Others are partly albitized and partially replaced by laumontite; a few are entirely replaced by laumontite as seen in thin section. In contrast to D13.2, XRD shows a sharp 14- $\AA$ chlorite peak and also smectite $(d=12.3 \AA$, expanding to $17.4 \AA$ with ethylene glycol solvation).

\section{Experimental methods}

Specimens used for TEM observations were studied first using an automated Philips XRG 2100 X-ray diffractometer. Ethylene glycol-solvated and untreated specimens were examined in order to determine the presence of expandable layers. Both bulk and claysized fractions were studied.

Thin sections were prepared with orientations perpendicular to the bedding plane. Following optical examination, 3-mm diameter washers were attached on selected areas of the thin section. After detaching from the slides these washer-mounted samples were ion-thinned and carbon-coated, and examined at $100 \mathrm{kV}$ in a JEOL
JEM-100CX scanning-transmission electron microscope (STEM) fitted with a solid-state detector for energy-dispersive analysis. One-dimensional lattice fringe images were obtained by using only 001 reflections as described by Ijima and Buseck (1978).

\section{TEM observations}

\section{The occurrence of phyllosilicates}

The bentonitic sediment from Kaka Point is composed mainly of smectite plus a subordinate clay of the kaoliniteserpentine groups. Smectite exhibits a typical curved lensshaped morphology in TEM images, lacking preferred orientation (Fig. 2). Many cracks occur within the smectite. These may be formed by collapse of smectite layers through dehydration during ion-thinning or TEM observations. Chlorite was not observed.

Chlorite was more frequently observed than illite in the analcime-rich and laumontite-rich samples. Most chlorite occurs as well-defined packets of layers that are very closely associated with illite (Fig. 3). Illite is commonly present as thin packets with chlorite, and the (001) interfaces are parallel and apparently coherent (Fig. 3). Individual illite layers also occur interlayered within chlorite (Fig. 3). Although the thickness of packets of chlorite layers is variable, most chlorite crystals are no thicker than $300 \AA$ and are occasionally as thin as $100 \AA \AA$. Most chlorite packets display a platy subhedral shape (Fig. 3). AEM and electron microprobe analyses indicated that chlorites in both sediments are $\mathrm{Fe}$ rich chlorite (Fig. 4) similar to Hokonui Hills chlorite (Boles and Coombs 1975, 1977).

Illite typically occurs as thin packets varying from 50 to $300 \AA$ in thickness, and is almost always closely associated with chlorite (Fig. 3). Illite layers are relatively straight and defect-free, with constant interlayer spacing. Such features are typical of illite as contrasted with smectite (Ahn and Peacor 1986). Packets of illite layers also exhibit a platy subhedral shape similar to that of chlorite crystals. No smectite was observed in images from both sediments,

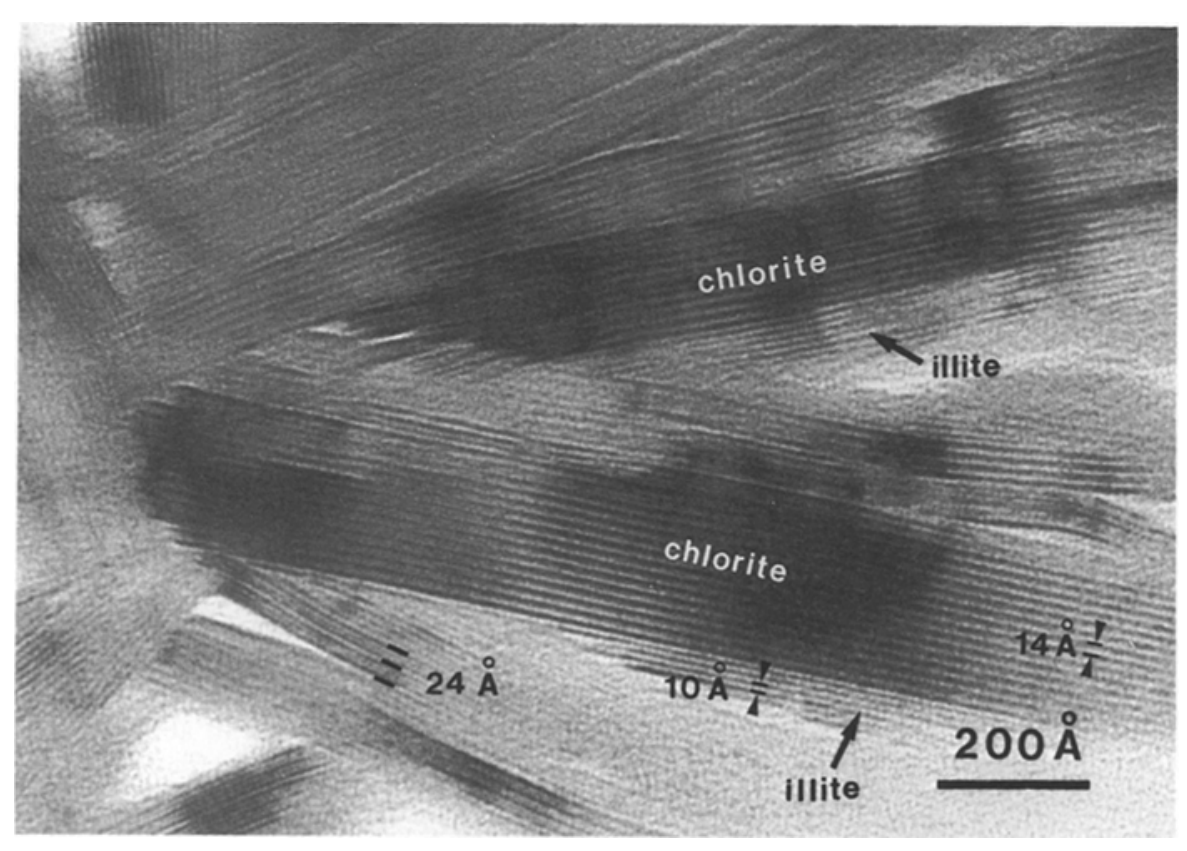

Fig. 3. TEM images of chlorite crystals. Illite overgrowths on chlorite with (001) interfaces. Small grain of $1: 1$ ordered mixed-layer illite/chlorite with $24-\AA$ periodicity is shown (D 22A, laumontite-rich tuff, Park's Cutting near Nugget Point) 

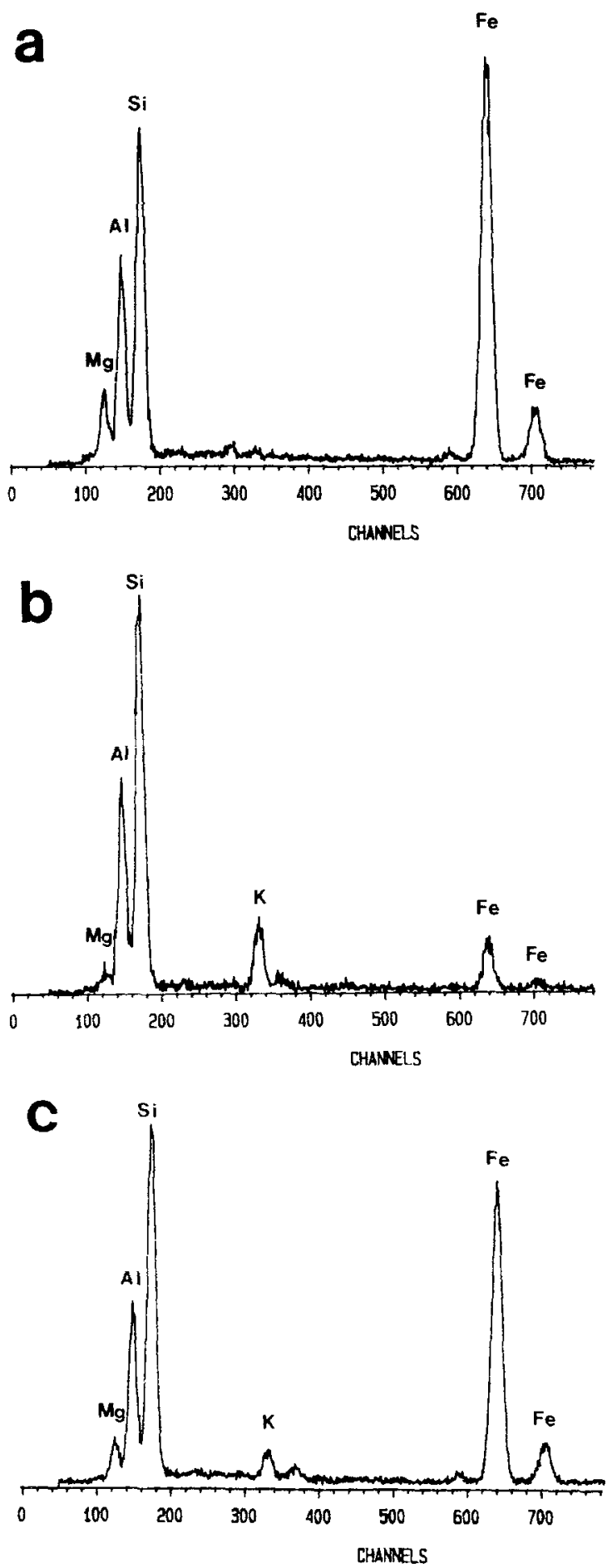

Fig. 4a-c. Energy dispersive X-ray spectra of typical chlorite a illite $\mathbf{b}$ and chlorite with interlayered illite layers $\mathbf{c}$ (from locality D 22, Nugget Point)

although minor smectite is certainly present in the laumontite-rich sample, as shown by the XRD pattern. The AEM analysis of illite indicated that it contains high $\mathrm{Al}$ and small amounts of $\mathrm{Fe}$ and $\mathrm{Mg}$ (Fig. 4b) confirming that it is illite rather than celadonite. No other phases with $10-\AA$ interlayer spacings were observed in the two samples studied. However, the presence of significant $\mathrm{CaO}$ (e.g. $0.6 \%$ ) in some "chlorite" studied by electron microprobe analysis

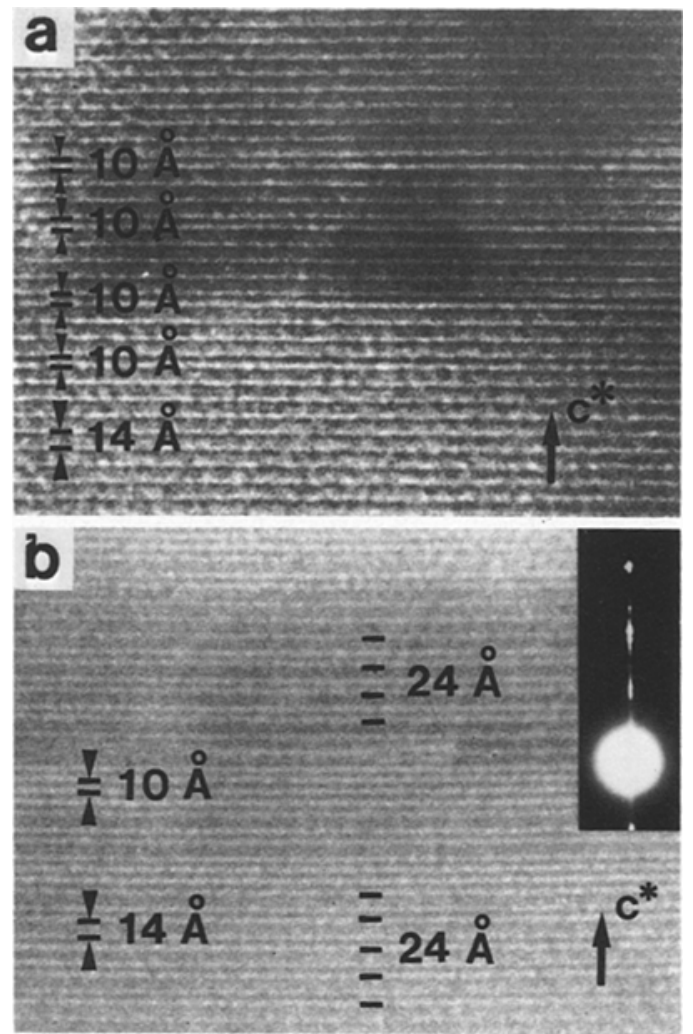

Fig. 5. a Chlorite from analcimized tuff, D 13.2, Kaka Point, containing interlayered illite, b Chlorite from D 22A Nugget Point, showing $24 \AA$ periodicity due to $1: 1$ ordered mixed-layering of chlorite and illite

of Hokonui Hills samples (Boles and Coombs 1975, 1977) suggests that mixed layer chlorite-smectite may occur in the Murihiku Supergroup rocks as well as the chlorite-illite mixtures here described and the celadonite and celadonitechlorite mixtures referred to above.

\section{Mixed-layering of chlorite and illite}

Illite crystals do not contain any interlayered chlorite, but illite is interlayered in most "chlorite" crystals (Fig. 6a), usually in a random way. In "chlorite", chlorite and illite layers locally occur ordered in a 1:1 sequence resulting in $24-\AA$ periodicity (Fig. 5 b). The presence of only 3 or 4 repetitions of $1: 1$ ordered sequences does not produce obvious $24-\AA$ periodicity in electron diffraction patterns (Fig. 5b). However, illite and chlorite layers do rarely occur interlayered in 1:1 ordered sequences that are extensive enough to give rise to well-defined reflections of $24-\AA$ periodicity; the $1: 1$ ordered sequences were observed with up to 11 repetitions (Fig. 6).

The mixed-layered domains have compositions intermediate between those of homogeneous chlorite and illite as shown by AEM analysis (Fig. 4c), implying that they consist of trioctahedral chlorite and dioctahedral illite. However, the AEM data are also compatible with mixed-layering of both 10 and $14-\AA$ layers which are compositionally intermediate between di- and trioctahedral (D.R. Veblen, personal communication, 1984; Lee and Peacor 1985), although such phases have not been reported and are considered to be unlikely. 


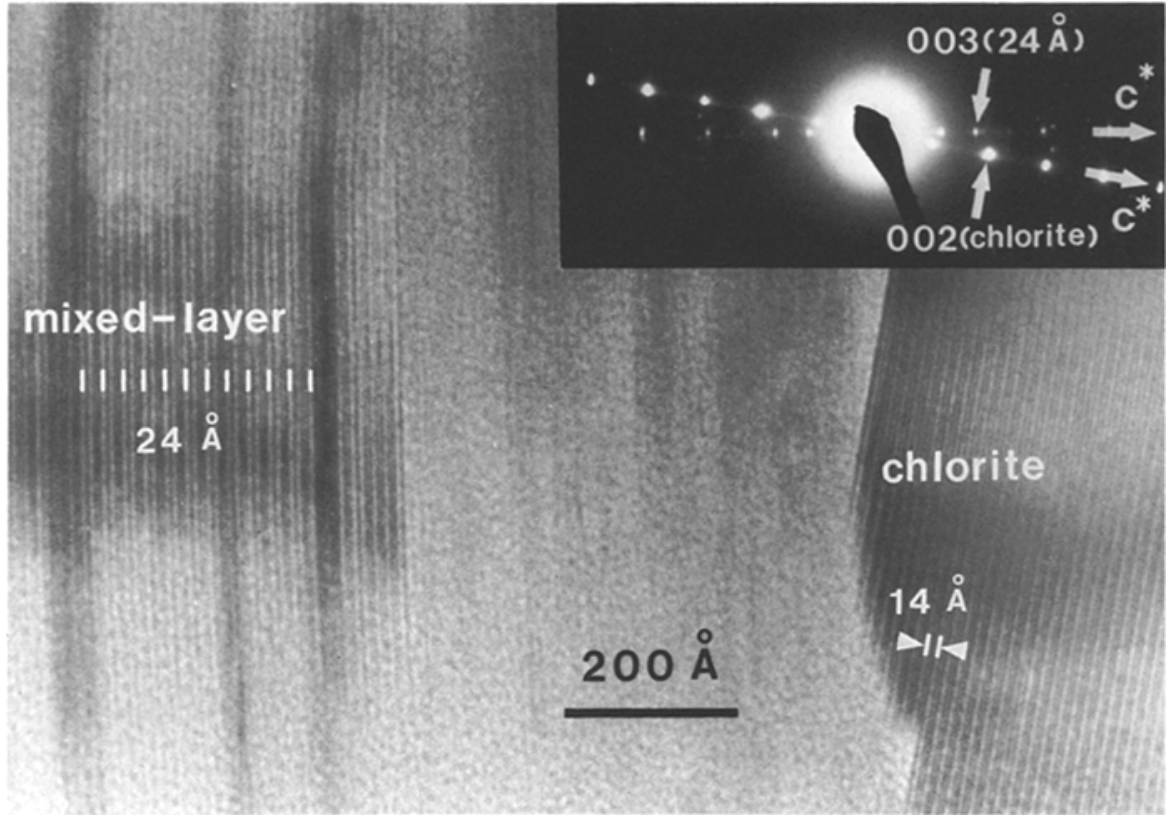

Fig. 6. Lattice fringe images of $1: 1$ ordered mixed-layer illite/chlorite which give rise to an electron diffraction pattern of $24-\AA$ periodicity

\section{Defect structures of illite and chlorite}

A single 14- $\AA$ chlorite layer is occasionally observed to give way laterally to a $10-\AA$ layer (Fig. 7a). Although individual 10-Å layers cannot be directly analyzed by AEM, the intimate association of illite and chlorite elsewhere implies that the $10-\AA$ layers are dioctahedral. The layer transition is therefore inferred to involve a change from a trioctahedral to a dioctahedral 2:1 layer.

A second type of layer transition is shown in Fig. $7 \mathrm{~b}$, where one $10-\AA$ layer passes laterally into a two-layer unit consisting of one $10-\AA$ and one $14-\AA$ layer. Many TEM studies have documented local intercalations of extra brucite-, serpentine-, and talc-like layers resulting in layer transitions (e.g., Iijima and Zhu 1982; Olives et al. 1983; Veblen 1983). However, intercalation of a complete $14-\AA$ chlorite layer consisting of talc-like and brucite-like layers has not been described previously.

Another type of imperfection consists of thin packets of $10-\AA$ layers occurring as small domains within chlorite crystals resulting in two types of interfaces (Fig. 8), one parallel and one non-parallel to (001). Packets of several $10-\AA$ layers give way to packets of $14-\AA$ layers along the non-parallel interfaces. Although intergrowth of illite with chlorite as thin packets is commonly seen in TEM studies (e.g., Lee et al. 1984), such transitions of packets along layers have not been reported previously.

\section{Discussion}

\section{Formation of chlorite and illite}

In typical argillaceous sediments, detrital smectite gives rise to authigenic illite and chlorite during burial metamorphism (e.g., Perry and Hower 1970; Weaver and Beck 1971; Hower et al. 1976; Ahn and Peacor 1985, 1986). In the Gulf Coast section thin packets of illite and chlorite layers are observed within a matrix of smectite, implying that both are formed by replacement of smectite (Ahn and Peacor 1986).
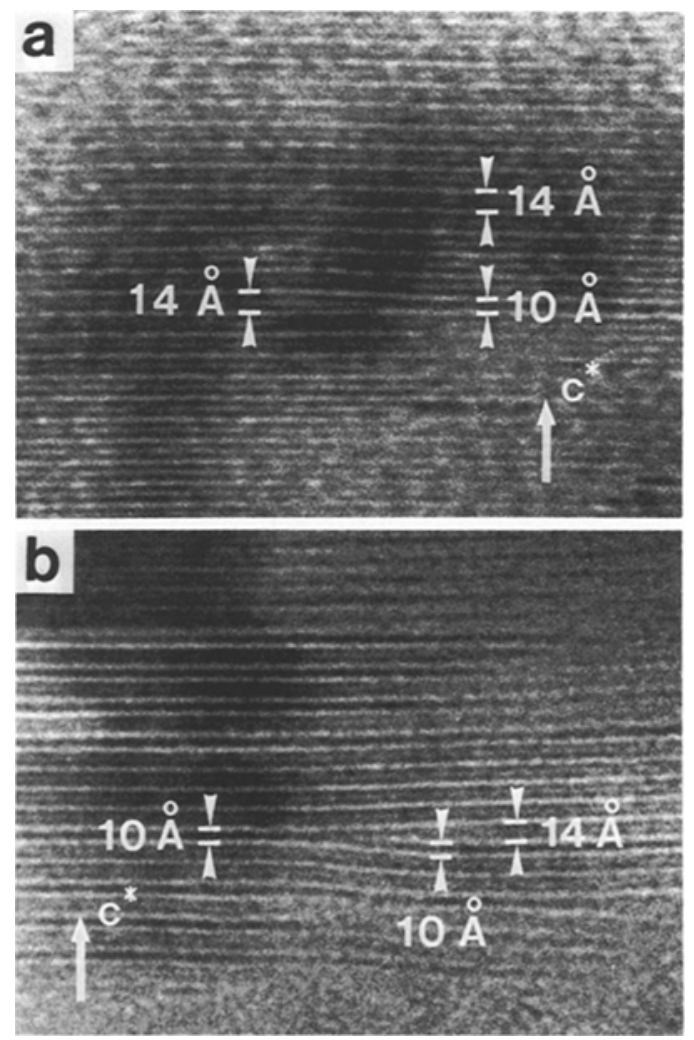

Fig. 7 a. Lattice fringe images showing a transition of one chlorite layer to one illite layer in D 13.2 from Kaka Point, b Layer transition of one illite layer to one illite plus one chlorite layer observed in $\mathrm{D} 22 \mathrm{~A}$

However, such relationships may be applicable only to relatively impermeable shales, the behavior of which approximates a closed system (Hower et al. 1976). Yau et al. (1984) and Yau and Peacor (1987) have reported a different mechanism for illite and chlorite formation in sediments of the Salton Sea geothermal field. They suggested that 


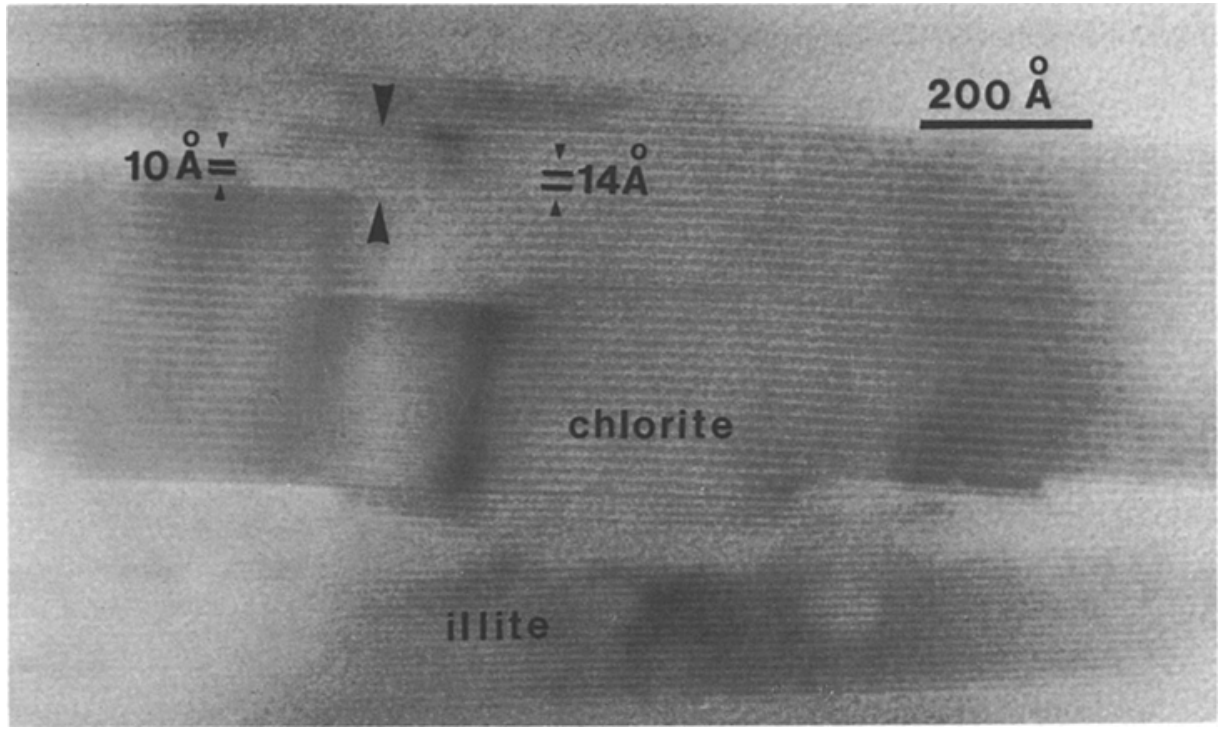

Fig. 8. Chlorite crystal from D 13.2, Kaka Point, containing illite packets with boundaries that are both parallel and at a high angle to (001). In addition, illite layers are present at the boundaries of the chlorite crystal with parallel or subparallel orientations both illite and chlorite that exhibit euhedral crystal shape formed through direct crystallization from mobile hypersaline fluids in an open, permeable system. The components for illite and chlorite were derived only in part through dissolution of detrital smectite and the process involves crystallization of euhedral crystals rather than direct replacement of precursor smectite.

The mode of occurrence of chloritic minerals in the Murihiku analcime and laumontite-rich tuffaceous sediments closely mimics that of smectite and heulandite in tuffs and even in the bentonites; i.e. they are concentrated along former glass shard boundaries and in microvesicles and matrix. This suggests that the mixed-layer chlorite-illites have formed at least in part from smectite. Nevertheless, the textures of chlorite and illite in the Murihiku zeolitic sediments as revealed by TEM are very similar to those in the Salton Sea geothermal field, in that most chlorite and illite show a characteristic platy subhedral to euhedral shape. In addition, thin packets of illite and chlorite layers which are apparently at an early stage of crystal growth are separate from smectite. This is in contrast to the occurrence of illite and chlorite in the Gulf Coast as described above. Furthermore, Yau et al. (1987) have observed illite, chlorite and mixed-layer illite/chlorite, with textures duplicating those of this study, as direct products of crystallization from solution in hydrothermal experiments. The textural features of illite and chlorite in the Murihiku zeolitic sediments are thus compatible with illite and chlorite formation through crystallization following dissolution of smectite. Although smectite is implied to be the source of at least some components, volcanic glass or mafic primary minerals such as biotite may also have been significant contributors.

\section{Correlation between burial depth and clay mineralogy}

The smectite in bentonitic sediments from Kaka Point is interpreted as an alteration product of volcanic ash, complementary to the heulandite that directly replaces glass shards in these rocks. Only a small proportion of illite
$(<20 \%)$ occurs in the mixed-layer illite/smectites, implying that little mineralogical change has occurred following burial. However, the analcime-rich sediment, D 13.2, which contains illite, chlorite, and mixed-layer illite/chlorite, is located within $800 \mathrm{~m}$ stratigraphically of the bentonitic sediment rich in smectite (D 21.6). Petrographically similar rocks, as confirmed by optical and XRD investigation, overlap stratigraphically, occurring both above and below D 13.2. Boles and Coombs (1975), on the basis of XRD studies, detected no systematic changes related to depth in smectite-rich bentonites throughout the $4.8-8.5 \mathrm{~km}$ Triassic section of the Hokonui Hills. This was observed in spite of the occurrence throughout the section, especially in the lower parts, of diagenetically or metamorphically more advanced albitized or laumontitized rocks. They documented the replacement of heulandite in an ash bed by laumontite (plus quartz and alkali feldspars) with simultaneous albitization of plagioclase and a sharp decrease in chloritic phyllosilicates, and $\mathrm{Fe}, \mathrm{Mg}$ whole-rock content. Boles and Coombs (1977) further found that alteration as measured by albitization in sandstones in the Murihiku sequence is closely related to grain size and hence by inference, to permeability, as well as to depth in the section. It may be relevant that the laumontite-rich chlorite-illitebearing tuff $\mathrm{D} 22 \mathrm{~A}$, is significantly coarser grained than the bentonite described here. Coombs et al. (1959) noted also that alteration of zeolites is more advanced in the Nugget Point area than at Kaka Point.

Such a lack of correlation between burial depth and the mineralogy of phyllosilicates and gross overlap in the range of zeolites implies that factors other than burial depth and temperature are important in determining the grade of diagenesis of very low-grade metamorphism. Boles and Coombs (1977) suggested that these factors include the relationship of fluid pressure to lithostatic pressure, reaction kinetics, fluid chemistry, and mobility of fluid, the latter being no doubt related to permeability. These relations, therefore, further imply that the apparent degree of conversion of smectite to illite is controlled by several factors, only one of which may be temperature in response to burial depth. 


\section{Intralayer transition from chlorite to illite}

Intralayer transitions between chlorite and 10- $\AA$ layers were commonly observed in this study (e.g., Fig. 7a). Such transitions can be interpreted either as the result of post-crystallization alteration of one phase to the other or as a feature of primary crystal growth, as with chain silicates (Veblen and Buseck 1980). If they formed as a result of post-crystallization alteration, the layer transition boundaries represent the sites of the layer to layer reaction. However, it is usually difficult to distinguish between the two origins without extensive microstructural and microchemical data (Veblen 1983).

Alteration of biotite to chlorite resulting in intercalated chlorite layers or layer transitions has been widely studied using TEM. Both biotite and chlorite have the same talclike structural unit in common, and simple replacement of the interlayer cations of biotite by a brucite-like layer can result in a chlorite layer (Iijima and Zhu 1982; Olives et al. 1983; Veblen 1983). In addition, two biotite layers can react to form one chlorite layer through the leaching out of two tetrahedral sheets of one T-O-T biotite layer (Veblen and Ferry 1983).

If $10-\AA$ layers are dioctahedral illite, insertion of a brucite-like layer in the interlayer cannot change illite to trioctahedral chlorite. Replacement of the interlayer cations of illite by a brucite-like layer would result in a dioctahedral chlorite such as sudoite (Eberl 1978). Therefore neither of the layer transition mechanisms that account for the alteration of biotite to chlorite (Veblen and Ferry 1983) are compatible with the alteration of illite to chlorite. In the Murihiku zeolitic tuffs, discrete illite and chlorite crystals appear to have formed through direct crystallization from solution rather than through transformation of other phases. Furthermore, very thin packets less than $100 \AA$ in thickness having mixed-layer structure of illite and chlorite are frequently observed, implying that these in thin packets crystallized originally as a mixed-layer structure. In addition, illite crystals never show any interlayering of chlorite layers; however, chlorite crystals commonly contain some illite layers, indicating that illite layers have not been replaced by chlorite. The textural, chemical and structural relationships therefore collectively imply that the layer transition structures between illite and chlorite formed during primary crystallization rather than as a result of a postcrystallization reaction.

\section{Implications of the occurrence of mixed-layering of illite and chlorite}

Mixed-layering of chlorite and trioctahedral micas has almost exclusively been attributed to layer alteration and replacement of trioctahedral micas (Iijima and Zhu 1982; Olives et al. 1983; Veblen 1983; Veblen and Ferry 1983; Yau et al. 1984; Eggleton and Banfield 1985), rather than as a primary product of crystallization. However, Schreyer et al. (1982) described kulkeite, an ordered mixed-layer chlorite/talc, as a product of prograde metamorphism.

On the other hand, the occurrence of mixed-layered chlorite and dioctahedral micas has previously been reported only from the Martinsburg Formation at Lehigh Gap, Pennsylvania (Lee et al. 1984), although chlorite and dioctahedral micas coexist over a wide range of diagenetic or metamorphic environments. Such mixed-layering in the Martinsburg is restricted to samples transitional from shale to slate (Lee et al. 1984; Lee and Peacor 1985). Lee and Peacor (1985) pointed out that the chemical difference between dioctahedral and trioctahedral phyllosilicates would result in a significant misfit at the interface and therefore that mixed-layer illite/chlorite is structurally unstable. The scarcity of reported mixed-layered chlorite and illite also implies that such structures may be relatively unstable, tending to disappear with advancing temperature (Lee et al. 1984; Lee and Peacor 1985) though their apparent scarcity may also be related to relative lack of study of very low temperature volcanogenic materials.

Incomplete reactions of minerals are common in Southland Syncline sediments, and equilibrium has generally not been attained (Boles and Coombs 1975). With a higher degree of metamorphism such mixed-layered crystals should disappear, and discrete crystals of chlorite and dioctahedral micas should replace the mixed-layer illite/chlorite as stable phases (Lee et al. 1984).

Acknowledgements. The authors are grateful to Dr. Y. Kawachi for electron microprobe analyses, to Drs. S. Guggenheim and J.R. Boles for helpful reviews of the manuscript, and to the University of Otago Research Committee for financial support. This work was supported by NSF grants EAR-8604170 and EAR-8313236 to D. R Peacor.

\section{References}

Ahn JH, Peacor DR (1985) Transmission electron microscopic study of diagenetic chlorite in Gulf Coast argillaceous sediments. Clays Clay Minerals 33:228-236

Ahn JH, Peacor DR (1986) Transmission and analytical electron microscopy of the smectite-to-illite transition. Clays Clay Minerals 34:165-179

Ahn JH, Peacor DR (1987) Transmission electron microscopic study of the diagenesis of kaolinite in Gulf Coast argillaceous sediments. Proc Int Clay Conf, Denver 1985:151-157

Boles JR (1971) Synthesis of analcime from natural heulandite and clinoptilolite. Am Mineral 56:1724-1734

Boles JR (1972) Composition, optical properties, cell dimensions, and thermal stability of some heulandite group zeolites. Am Mineral 57:1463-1493

Boles JR, Coombs DS (1975) Mineral reactions in zeolitic Triassic tuff, Hokonui Hills, New Zealand. Geol Soc Amer Bull $86: 163-173$

Boles JR, Coombs DS (1977) Zeolite facies alteration of sandstones in the Southland Syncline, New Zealand. Am J Sci 277:982-1012

Cho M, Maruyama S, Liou JG (1986) The stability of heulandite in the system $\mathrm{CaAl}_{2} \mathrm{Si}_{2} \mathrm{O}_{8}-\mathrm{SiO}_{2}-\mathrm{H}_{2} \mathrm{O}$. Abstracts with Program, 14th General Meeting, International Mineralogical Assoc, 13-18 July 1986. Stanford Univ, Calif: p 76

Coombs DS (1954) The nature and alteration of some Triassic sediments from Southland, New Zealand. Trans Royal Soc New Zealand 82:65-109

Coombs DS (1961) Some recent work on the lower grades of metamorphism. Australian J Sci 24:203-215

Coombs DS (1965) Sedimentary analcime rocks and sodium-rich gneisses. Mineral Mag 34:144-158

Coombs DS, Campbell JD, McKeller IC, Landis CA, Bishop DG (1976) Regional geology of southern part of South Island, New Zealand Geosyncline. 25th International Geological Congress, Excursion Guide No. $59 \mathrm{c}: 36 \mathrm{p}$

Coombs DS, Ellis AJ, Fyfe WS, Taylor AM (1959) The zeolite facies, with comments on the interpretation of hydrothermal syntheses. Geochim Cosmochim Acta 17:53-107

Curtis CD, Hughes CR, Whiteman JA, Whittle CK (1985) Compositional variation within some sedimentary chlorite and some comments on their origin. Mineral Mag 49:375-386 
Eberl D (1978) Reaction series for dioctahedral smectite. Clays Clay Minerals 26:327-340

Eggleton RA, Banfield JF (1985) The alteration of granitic biotite to chlorite. Am Mineral 70:902-910

Hower J, Eslinger E, Hower ME, Perry EA (1976) Mechanism of burial metamorphism of argillaceous sedimen: 1. Mineralogical and chemical evidence. Geol Soc Amer Bull 87:725-737

Iijima S, Buseck PR (1978) Experimental study of disordered mica structures by high-resolution electron microscopy. Acta Crystallogr A34:709-719

Iijima S, Zhu J (1982) Electron microscopy of a muscovite-biotite interface. Am Mineral 67:1195-1205

Lee JH, Peacor DR (1985) Ordered 1:1 interstratification of illite and chlorite: a transmission and analytical electron microscopy study. Clays Clay Minerals 33:463-467

Lee JH, Peacor DR, Lewis DD, Wintsch RP (1984) Chlorite-illite/ muscovite interlayered and interstratified crystals: a TEM/ STEM study. Contrib Mineral Petrol 88:372-385

Liou JG (1971) Analcime equilibria. Lithos 4:389-402

McKellar IC (1966) Sheet 25, Dunedin (1st ed.), Geological Map of New Zealand 1:250000. Department of Scientific and Industrial Research, Wellington, New Zealand

Olives BJ, Amouric M, de Fouquet C, Baronnet A (1983) Interlayering and interlayer slip in biotite as seen by HRTEM. Am Mineral 68:754-758

Perry E, Hower J (1970) Burial diagenesis in Gulf Coast pelitic sediments. Clays Clay Minerals 18:165-177

Schreyer W, Medenbach O, Abraham K, Bergert W, Muller WF (1982) Kulkeite, a new metamorphic mineral: ordered 1:1 chlorite/talc mixed-layer. Contrib Mineral Petrol 80:103-109

Veblen DR (1983) Microstructures and mixed-layering in inter- grown wonesite, chlorite, talc, biotite, and kaolinite. Am Mineral $68: 566-580$

Veblen DR, Buseck PR (1980) Microstructures and reaction mechanisms in biopyriboles. Am Mineral 65:599-623

Veblen DR, Ferry JM (1983) A TEM study of the biotite-chlorite reaction and comparison with petrologic observations. Am Mineral 68:1160-1168

Weaver CE, Beck KC (1971) Clay-water diagenesis during burial: how mud becomes gneiss. Geol Soc Amer Spec Paper 134:96p

Yau YC, Anovitz LM, Essene EJ, Peacor EJ (1984) Phlogopitechlorite reactions during retrograde reaction in the Marble Formation, Franklin, New Jersey. Contrib Mineral Petrol 88:299-308

Yau YC, Peacor DR (1987) Smectite-to-illite reactions in Salton Sea shales: a transmission and analytical electron microscopy study. J Sed Petrol 57:335-343

Yau YC, Peacor DR, Essene EJ, Lee JH, Kuo LC, Cosca MA (1987) Hydrothermal treatment of smectite, illite, and basalt to $460^{\circ} \mathrm{C}$ : comparison of natural with hydrothermally formed clay minerals. Clays Clay Minerals 35:241-250

Yau YC, Peacor DR, McDowell SD (1984) TEM/AEM study of chlorite diagenesis in well I.I.D. No. 2 in Salton Sea geothermal field, California. Progr Abstr 21st Ann Mtg, Clay Minerals Soc 1984: p 120

Zen E (1961) The zeolite facies: an interpretation. Am J Sci 259:401-409

Zen E (1974) Burial metamorphism. Can Mineral 12:445-455

Received February 16, 1987 / Accepted December 14, 1987

Editorial responsibility: I.S.E. Carmichael 